\title{
Overexpression of initiator methionine tRNA leads to global reprogramming of tRNA expression and increased proliferation in human epithelial cells
}

\author{
MARIANA PAVON-ETERNOD, ${ }^{1}$ SUZANA GOMES, ${ }^{2}$ MARSHA R. ROSNER, ${ }^{2,3}$ and TAO PAN ${ }^{1,3}$ \\ ${ }^{1}$ Department of Biochemistry and Molecular Biology, University of Chicago, Chicago, Illinois 60637, USA \\ ${ }^{2}$ Ben May Department of Cancer Research, University of Chicago, Chicago, Illinois 60637, USA
}

\begin{abstract}
Transfer RNAs (tRNAs) are typically considered housekeeping products with little regulatory function. However, several studies over the past 10 years have linked tRNA misregulation to cancer. We have previously reported that tRNA levels are significantly elevated in breast cancer and multiple myeloma cells. To further investigate the cellular and physiological effects of tRNA overexpression, we overexpressed $t R N A_{i}^{\text {Met }}$ in two human breast epithelial cell lines. We then determined tRNA abundance changes and performed phenotypic characterization. Overexpression of $\operatorname{tRNA}_{i}^{\text {Met }}$ significantly altered the global tRNA expression profile and resulted in increased cell metabolic activity and cell proliferation. Our results extend the relevance of tRNA overexpression in human cells and underscore the complexity of cellular regulation of tRNA expression.
\end{abstract}

Keywords: initiator methionine tRNA; tRNA; tRNA microarrays

\section{INTRODUCTION}

Misregulation of components of the translation machinery is characteristic of many types of tumor cells and can lead to malignant transformation (Bjornsti and Houghton 2004; Pandolfi 2004). Abnormally high levels of RNA polymerase III transcripts, including tRNA and 5S rRNA which are directly involved in translation, are found in a wide variety of transformed cell types (Marshall and White 2008). These cell types include cell lines transformed by DNA tumor viruses (such as hepatitis B virus), RNA tumor viruses (such as human T-cell leukemia virus 1), and chemical carcinogens. These observations have also been confirmed for tumors in situ by RT-PCR, Northern blot, and more recently by microarray analysis (Chen et al. 1997a,b; Winter et al. 2000; PavonEternod et al. 2009). We have previously reported that tRNA levels are elevated in breast cancer and multiple myeloma cell lines (Pavon-Eternod et al. 2009; Zhou et al. 2009). Though abnormal RNA polymerase III activity has long been associated with cancer, it remains unclear whether it contributes to

Abbreviations: $\mathrm{tRNA}_{\mathrm{i}}^{\mathrm{Met}}$, initiator methionine $\mathrm{tRNA}$; $\mathrm{RNA}_{\mathrm{e}}^{\mathrm{Met}}$, elongator methionine tRNA

${ }^{3}$ Corresponding authors

E-mail mrosner@uchicago.edu

E-mail taopan@uchicago.edu

Article published online ahead of print. Article and publication date are at http://www.rnajournal.org/cgi/doi/10.1261/rna.037507.112. malignant transformation or is simply a byproduct of the cell's cancer state.

Due to its unique function in translation initiation, we are particularly interested in the role of the initiator methionine tRNA ( $\mathrm{tRNA}_{\mathrm{i}}^{\mathrm{Met}}$ ) in cancer. An appealing possibility is that overexpression of $t \mathrm{RNA}_{\mathrm{i}}^{\mathrm{Met}}$ could alter the translational regulation of key genes involved in tumorigenesis. The effect may be both quantitative and qualitative: Overall protein synthesis may be increased, and mRNAs encoding cell-cycle or antiapoptic proteins (such as Myc or cyclin D1) may be preferentially translated. To explore this question in the context of breast cancer, we set out to overexpress tRNA $A_{i}^{\text {Met }}$ in human breast epithelial cell lines. Overexpressing tRNAs in human cell lines, however, proved more challenging than we had expected. Here we present our experimental approach to tRNA overexpression and a phenotypic characterization of the resulting cell lines (Fig. 1). We find that tRNA overexpression in human cells requires the generation of stable cell lines, and that only modest increases (1.4- to 2.2-fold) can be achieved. Remarkably, overexpression of $\mathrm{tRNA}_{\mathrm{i}}^{\mathrm{Met}}$ in both epithelial cell lines changed the levels of other tRNAs, reprogramming the global tRNA expression profile. $\mathrm{RNA}_{\mathrm{i}}^{\mathrm{Met}}$ overexpression also resulted in increased metabolic activity and cell proliferation. Our results underscore the need for caution in interpreting the effects of individual tRNA overexpression, as little is known about the regulation of individual tRNA expression in the cell. 


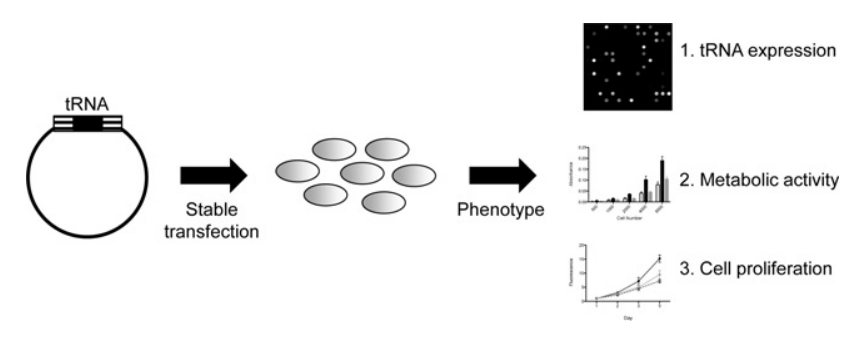

FIGURE 1. Experimental strategy for tRNA overexpression. The tRNA gene of interest with 200-bp flanking regions was cloned into a mammalian expression vector, then stably transfected into the human cell line. The stable cell line was then characterized in terms of tRNA expression profile, metabolic activity, and cell proliferation.

\section{RESULTS AND DISCUSSION}

\section{Experimental strategies for tRNA overexpression}

Because tRNAs are generally considered non-regulatory housekeeping genes, there are no well-established methods for manipulating the levels of specific tRNAs in mammalian cells. Furthermore, because tRNAs are highly abundant, overexpression even by twofold would require an additional transcription of $\sim 1,000,000$ molecules of $\mathrm{tRNA}_{\mathrm{i}}^{\mathrm{Met}}$ per cell (Pavon-Eternod et al. 2009). In the past, exogenous tRNA has been introduced into cells either as DNA or directly as RNA (Carbon et al. 1983; Buvoli et al. 2000). We tried three different approaches to increase $\mathrm{RNA}_{\mathrm{i}}^{\text {Met }}$ levels in two human cell lines: transient transfection with tRNA transcripts, transient transfection with a DNA vector containing the tRNA gene, and stable transfection with a DNA vector containing the tRNA gene. We selected the human breast epithelial cell lines 184A1 and MCF10A for these experiments for the following reasons: (i) They are non-tumorigenic cell lines, (ii) our previous work has shown 184A1 and MCF10A have relatively low levels of tRNA (Pavon-Eternod et al. 2009), and (iii) they are readily transfectable.

Our first approach relied on transient transfection of $\mathrm{tRNA}_{\mathrm{i}}^{\mathrm{Met}}$ and $\mathrm{RNNA}_{\mathrm{e}}^{\mathrm{Met}}$ transcripts. In vitro transcribed tRNAs have been reported to be active in translation when transfected into eukaryotic cells. Indeed, they have been used to insert unnatural amino acids into proteins and to induce amino acid substitutions resulting in widespread proteome damage in mammalian cells (Kohrer et al. 2001; Geslain et al. 2010). In vitro transcribed tRNAs are simple to synthesize and allow direct control over the amount of tRNA transfected. However, the question remains whether they are truly fully functional in the cell. In vitro transcribed tRNAs lack the post-transcriptional modifications characteristic of endogenous tRNAs that serve as identity determinants, contribute to tRNA stability, and impact translational accuracy (Alexandrov et al. 2006; Agris et al. 2007; Waas et al. 2007; Phizicky and Hopper 2010). This is particularly relevant for our tRNA of interest: $\mathrm{tRNA}_{\mathrm{i}}^{\mathrm{Met}}$ transcripts lacking the $\mathrm{m}^{1} \mathrm{~A}_{58}$ modification are subject to nuclear polyadenylation and rapid degradation (Kadaba et al. 2004, 2006; Vanacova et al. 2005). In any case, we found that in vitro transcribed tRNAs were toxic to MCF10A cells when transfected at high enough concentrations to detectably increase cellular tRNA levels (data not shown).

Our second approach relied on transient transfection of a DNA vector containing a tRNA $\mathrm{R}_{\mathrm{i}}^{\text {Met }}$ or $\mathrm{tRNA}_{\mathrm{e}}^{\text {Met }}$ gene into MCF10A cells. Fragments containing the tRNA gene were PCR-amplified from human genomic DNA and cloned into the pTarget Mammalian Expression Vector. The fragments contained 200 base pairs each upstream of and downstream from the endogenous tRNA gene, which should include all the regulatory elements necessary for tRNA transcription (Geiduschek and Kassavetis 2001; Dieci et al. 2007). This approach is experimentally straightforward and allows the transfection of large amounts of DNA without inducing toxicity. High-copy plasmids have been successfully used to induce tRNA overexpression in yeast and bacteria (Borel et al. 1993; Anderson et al. 1998; Sorensen et al. 2005). Again, transfection with our tRNA vectors did not result in any detectable increase in tRNA levels (data not shown).

Our third approach involved the generation of stable cell lines after transfection with our tRNA $\mathrm{A}_{\mathrm{i}}^{\mathrm{Met}}, \mathrm{tRNA}_{\mathrm{e}}^{\mathrm{Met}}$, and empty control vectors. Using this approach, we successfullygenerated an 184A1 cell line and an MCF10A cell line overexpressing tRNA $_{i}^{\text {Met }}$ relative to the control cell line (Fig. 2). From this point forward, we designate these cell lines 184A1-tRNA $A_{i}^{\text {Met }}$ and MCF10A-tRNA $A_{i}^{\text {Met }}$. The levels of tRNA $A_{i}^{\text {Met }}$ increased by 1.4- and twofold, respectively, as measured by tRNA microarrays. This level is comparable to that observed in breast cancer cell lines relative to non-tumorigenic breast epithelial cell lines (Pavon-Eternod et al. 2009). We were, however, unable to generate either a $184 \mathrm{~A} 1$ or MCF10A cell line overexpressing tRNA $\mathrm{e}_{\mathrm{e}}^{\mathrm{Met}}$ relative to the control cell line (Fig. 2A).

To confirm our microarray data, we analyzed tRNA $A_{i}^{\text {Met }}$ and tRNA $_{\mathrm{e}}^{\text {Met }}$ content in our 184A1 cell lines (control, 184A1tRNA $_{i}^{\text {Met }}$, and MCF10A-tRNA ${ }_{i}^{\text {Met }}$ ) by dot blot (Fig. 2B). In all cases, the microarray and dot blot data were in very good agreement. Our selective fluorophore labeling method requires that all tRNAs measured by microarrays contain 3'CCA (Pavon-Eternod et al. 2009) which is characteristic of all mature tRNAs. The agreement between microarray, which measures mature tRNA, and dot blot data, which measure mature and precursor tRNA, indicates that the observed $\mathrm{tRNA}_{\mathrm{i}}^{\mathrm{Met}}$ overexpression is primarily derived from mature tRNA.

\section{tRNA $A_{i}^{\text {Met }}$ overexpression generates unique tRNA expression profiles}

Unexpectedly, $\mathrm{tRNA}_{\mathrm{i}}^{\mathrm{Met}}$ overexpression induced a significant change in the levels of other tRNAs. Compared with the corresponding control line, median nuclear-encoded tRNA abundance increased by 1.4 -fold in $184 \mathrm{~A} 1-\mathrm{tRNA}_{\mathrm{i}}^{\mathrm{Met}}$ and 2.2fold in MCF10A-tRNA $\mathrm{i}_{\mathrm{iet}}$, whereas median mitochondrial- 
A

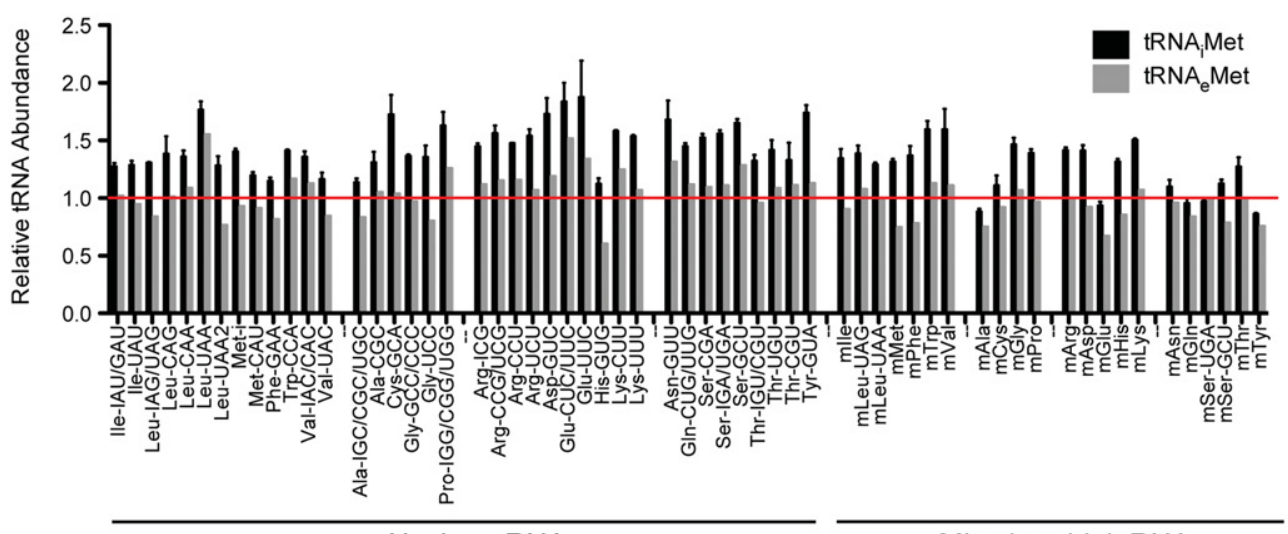

Nuclear tRNA

Mitochondrial tRNA

B

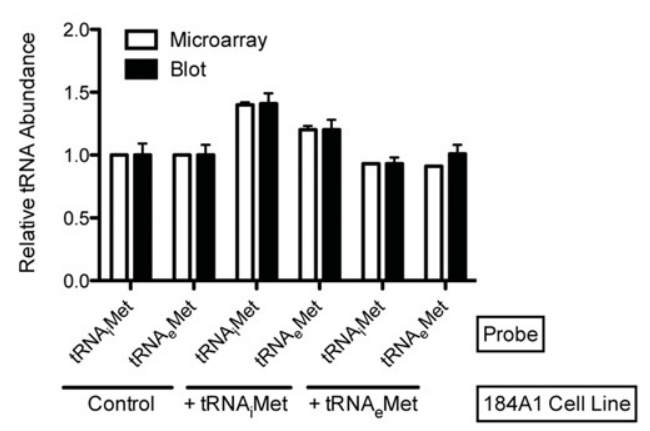

C

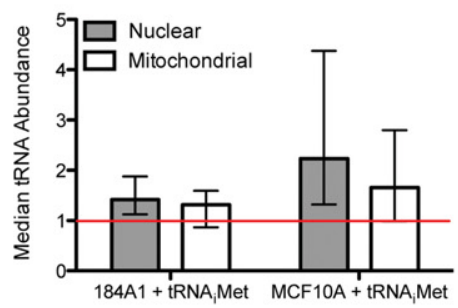

D

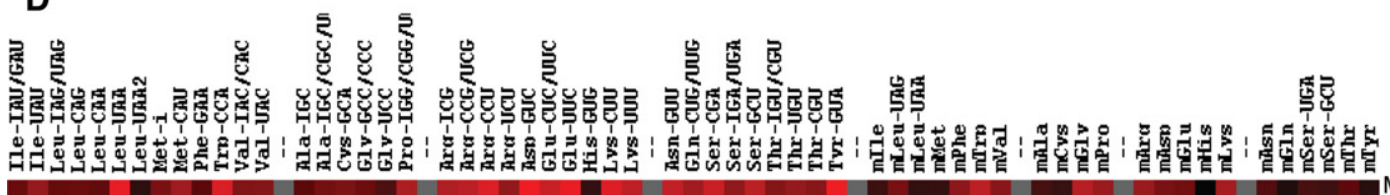

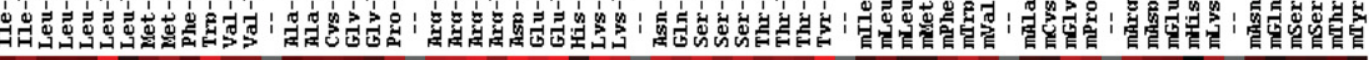

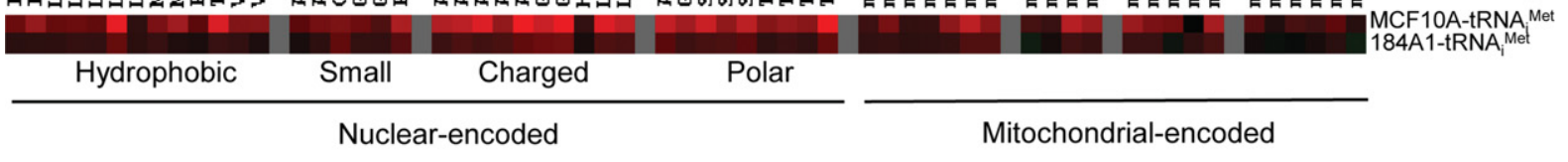

E

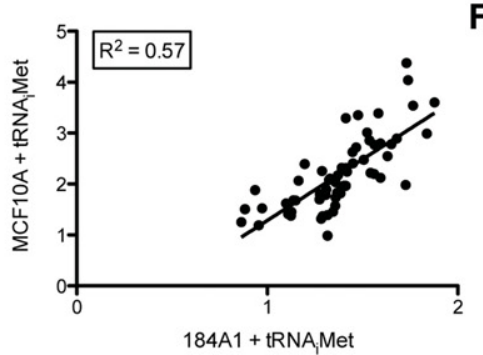

$\mathbf{F}$

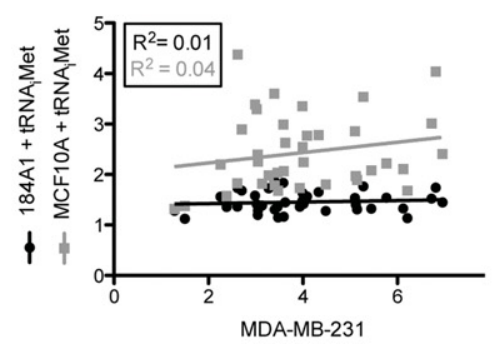

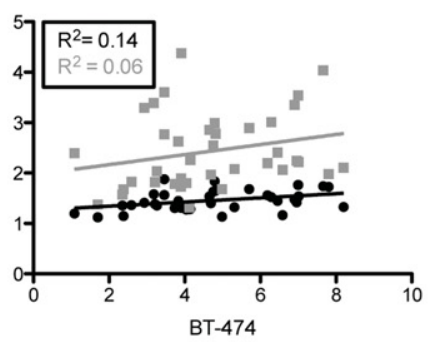

FIGURE 2. tRNA $_{i}^{\mathrm{Met}}$ overexpression generates unique tRNA expression profiles. (A) Individual tRNA abundances in $184 \mathrm{~A} 1-\mathrm{tRNA} \mathrm{A}_{\mathrm{i}}^{\mathrm{Met}}$ and $184 \mathrm{Al}-$

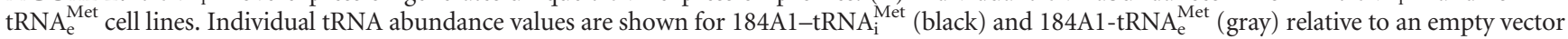
control cell line (set to 1, red line). A value of 1 indicates no change, a value $<1$ indicates a decrease, and a value $>1$ indicates an increase in tRNA levels relative to the control cell line. Data are grouped according to amino acid type. The $\mathrm{RNA}_{\mathrm{i}}^{\mathrm{Met}}$ and $\mathrm{tRNA} \mathrm{e}_{\mathrm{e}}^{\mathrm{Met}}$ probes are labeled Met-i and Met-CAU, respectively. Where error bars are present, values are averages from dye-swapped experiments and error bars indicate standard deviation. One sample $t$-test was performed to determine the statistical significance of the changes: ${ }^{*} P$-value $<0.05$. (B) Validation of microarray data by dot blot. As in $A$, relative tRNA abundance is defined as the ratio between the indicated cell line and the control cell line. Relative tRNA abundance values obtained by microarray (white) and dot blot (black, average of three replicates, error bars indicate standard deviation) are plotted for tRNA $\mathrm{Aet}_{\mathrm{i}}^{\mathrm{Met}}$ and tRNA $\mathrm{e}_{\mathrm{e}}^{\mathrm{Met}}$ in the three $184 \mathrm{Al}$ cell lines generated for this study (control, $184 \mathrm{Al}-\mathrm{tRNA}_{\mathrm{i}}^{\mathrm{Met}}$ and $184 \mathrm{Al}-\mathrm{tRNA}_{\mathrm{e}}^{\mathrm{Met}}$ ). $(C)$ Median tRNA abundance upon tRNA $\mathrm{i}_{\mathrm{i}}^{\mathrm{Met}}$ overexpression. Median values for $184 \mathrm{Al}-\mathrm{tRNA} \mathrm{i}_{\mathrm{Met}}$ and MCF10A-tRNA $\mathrm{i}_{\mathrm{i}}^{\mathrm{Met}}$ relative to control cell lines (set to 1 , red line). Median values for nuclearencoded tRNAs (gray) and mitochondrial-encoded (white) tRNAs are shown. The upper and lower bars indicate the range of individual tRNA abundances. $(D)$ Heat map of tRNA abundances upon $\mathrm{tRNA}_{\mathrm{i}}^{\text {Met }}$ overexpression. Relative tRNA abundance levels of nuclear and mitochondrial-encoded tRNAs in $184 \mathrm{~A} 1-\mathrm{tRNA}_{\mathrm{i}}^{\mathrm{Met}}$ and MCF10A-tRNA $\mathrm{i}$ Met are shown as TreeView images. Data are grouped according to amino acid type. Green indicates a decreased level of expression, red indicates an increased level of expression, and black indicates no change in expression level relative to the reference sample. (E) Individual tRNA abundances in $184 \mathrm{~A} 1-\mathrm{tRNA} \mathrm{i}_{\mathrm{i}}^{\text {et }}$ compared with MCF10A-tRNA $\mathrm{i}_{\mathrm{i}}$. Individual tRNA abundance values for $184 \mathrm{Al}-$ tRNA $_{i}^{\mathrm{Met}}$ and MCF10A-tRNA $\mathrm{i}_{\mathrm{Met}}$ are relative to the corresponding control cell lines. $(F)$ Individual nuclear-encoded tRNA abundances in two breast

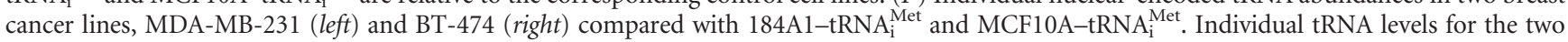
breast cancer cell lines, MDA-MB-231 and BT-474, are relative to the breast epithelial MCF10A cell line. Individual tRNA levels for the 184A1$\mathrm{tRNA}_{\mathrm{i}}^{\mathrm{Met}}$ and MCF10A-tRNA $\mathrm{i}_{\mathrm{M}}^{\text {Met }}$ cell lines are relative to the corresponding control cell lines. 
encoded tRNA abundance increased by 1.3 -fold in 184A1$\mathrm{tRNA}_{i}^{\mathrm{Met}}$ and 1.7-fold in MCF10A-tRNA $\mathrm{Aet}^{\mathrm{Met}}$ (Fig. 2C). These changes are more striking for individual tRNAs (Fig. 2A,D). Due to the nature of our microarray measurements, we express individual tRNA abundances in 184A1$\mathrm{tRNA}_{\mathrm{i}}^{\mathrm{Met}}$ and MCF10A-tRNA ${ }_{i}^{\mathrm{Met}}$ relative to the corresponding control cell line. While some tRNAs are increased up to fourfold upon $\mathrm{RNA}_{\mathrm{i}}^{\mathrm{Met}}$ overexpression, others are not affected. Remarkably, $\mathrm{tRNA}_{\mathrm{i}}^{\mathrm{Met}}$ overexpression generates very similarly altered expression profiles for nuclear-encoded tRNAs in both $184 \mathrm{~A} 1$ and MCF10A cell lines $\left(R^{2}=0.57\right.$, Fig. $\left.2 \mathrm{E}\right)$.

We also compared whether the tRNA expression profiles induced by $\mathrm{tRNA}_{\mathrm{i}}^{\mathrm{Met}}$ overexpression in breast epithelial lines are similar to those measured in breast cancer cell lines. Our previous study of tRNA expression in breast cancer revealed that tRNA overexpression is characteristic of breast cancer cells, and that this overexpression is highly selective based on tRNA identity (Pavon-Eternod et al. 2009). We therefore plotted tRNA levels (relative to the breast epithelial cell line MCF10A) in two breast cancer cell lines, MDA-MB-231 and BT-474, vs. the tRNA levels (relative to the corresponding control cell line) in our $184 \mathrm{~A} 1-\mathrm{tRNA}_{\mathrm{i}}^{\mathrm{Met}}$ and MCF10A$\mathrm{tRNA}_{\mathrm{i}}^{\mathrm{Met}}$ cell lines. We find a very poor correlation between the tRNA levels in bona fide breast cancer cell lines and the tRNA levels induced by $\mathrm{tRNA}_{\mathrm{i}}^{\text {Met }}$ overexpression $\left(R^{2}<0.15\right.$ in all cases) (Fig. 2F). While the tRNAs carrying charged and polar amino acids were consistently among the most overexpressed tRNAs in the breast cancer cell lines examined, we observe no such trends in our $184 \mathrm{~A} 1-\mathrm{tRNA}_{\mathrm{i}}^{\mathrm{Met}}$ and MCF10AtRNA $_{\mathrm{i}}^{\mathrm{Met}}$ lines.

\section{Initiator methionine tRNA overexpression leads to increased cell metabolism and proliferation}

Elevated tRNA levels are characteristic of breast cancer cells (Pavon-Eternod et al. 2009) which often exhibit altered metabolic activity and unregulated growth compared with noncancer cells. We therefore measured the metabolic activity and cell proliferation of $184 \mathrm{~A} 1-\mathrm{tRNA}_{\mathrm{i}}^{\mathrm{Met}}$ relative to the 184A1-control cell line (Fig. 3). We also included the $184 \mathrm{~A} 1-\mathrm{tRNA} \mathrm{e}_{\mathrm{e}}^{\mathrm{Met}}$ cell line as an additional control: Even though $\mathrm{tRNA}_{\mathrm{e}}^{\mathrm{Met}}$ expression was not increased in this line as we had expected, we detected punctual changes in the levels of several other tRNAs (such as tRNA ${ }^{\text {Leu(UAA) }}$ and tRNAGlu ${ }^{(\mathrm{CUC} / \mathrm{UUC})}$ ) (Fig. 2A), which may have an effect. We first measured the metabolic activity using two assays: Calcein AM, which relies on the activity of cytoplasmic esterases, and WST1, which relies on the activity of mitochondrial dehydrogenases. Both assays showed increased metabolic activity for $184 \mathrm{~A} 1-\mathrm{tRNA} \mathrm{i}_{\mathrm{i}}^{\mathrm{Met}}$ relative the control cell line, but no change in metabolic activity for $184 \mathrm{~A} 1-\mathrm{tRNA} \mathrm{e}_{\mathrm{Met}}^{\mathrm{M}}$. We also measured cell proliferation by Hoechst staining. Again, 184A1-tRNA ${ }_{i}^{\text {Met }}$ showed increased cell proliferation relative to the control cell line, but no significant change was seen for $184 \mathrm{~A} 1-\mathrm{tRNA} \mathrm{e}_{\mathrm{Met}}$.
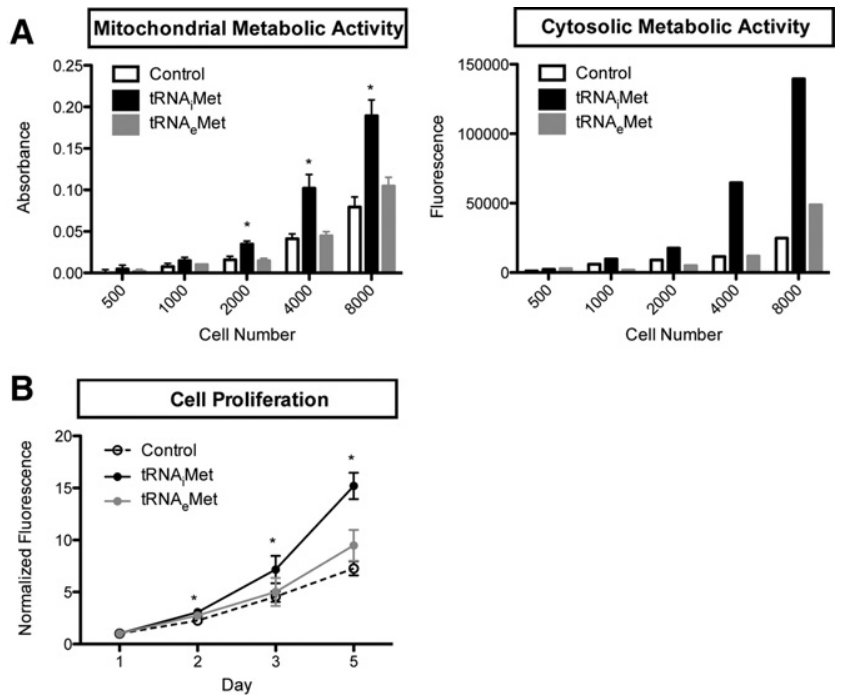

FIGURE 3. $\mathrm{tRNA}_{\mathrm{i}}^{\mathrm{Met}}$ overexpression leads to increased cell metabolism and proliferation. Data are shown for the $184 \mathrm{~A} 1$ cell lines 184A1-control, $184 \mathrm{~A} 1-\mathrm{tRNA}_{\mathrm{i}}^{\mathrm{Met}}$, and $184 \mathrm{~A} 1-\mathrm{tRNA} \mathrm{e}_{\mathrm{Met}}$. T-tests were performed to determine the statistical significance of the differences observed relative to $184 \mathrm{~A} 1$-control: ${ }^{*} P$-value $<0.05$. (A) Metabolic activity. Mitochondrial metabolic activity was measured by WST1, which relies on the activity of mitochondrial dehydrogenases. Cytosolic metabolic activity was measured by Calcein AM, which relies on the activity of cytoplasmic esterases. Where error bars are indicated, assays were performed in triplicate and the error bars indicate standard deviation. (B) Cell proliferation. Cell proliferation was measured over $5 \mathrm{~d}$ by Hoechst DNA staining. The assays were performed in triplicate; error bars indicate standard deviation.

\section{Concluding remarks}

In our experience, overexpressing a specific tRNA in human cell lines is not trivial. Of three possible approaches attempted by us, only one was successful: the generation of stable cell lines after transfection with a DNA vector containing the tRNA gene. Even so, we were able to generate cell lines stably overexpressing the desired tRNA for only one of two tRNAs. While we successfully generated stable cell lines overexpressing $\mathrm{tRNA}_{\mathrm{i}}^{\mathrm{Met}}$, we were unable to generate stable cell lines overexpressing $\mathrm{tRNA}_{\mathrm{e}}^{\mathrm{Met}}$ to any detectable level. This may be due to some intrinsic properties of $\mathrm{tRNA}_{\mathrm{e}}^{\mathrm{Met}}$, or other random factors such as the site of integration and copy number. Our results also indicate that manipulating the levels of one specific tRNA - in this case $\mathrm{tRNA}_{i}^{\mathrm{Met}}$ — significantly affects the levels of other tRNAs in the cell, suggesting some kind of feedback regulatory mechanism in the cell. Remarkably, $\mathrm{tRNA}_{\mathrm{i}}^{\mathrm{Met}}$ overexpression in two different cell lines resulted in similar patterns of tRNA expression. We expect that the tRNA expression profile induced by overexpressing a specific tRNA is dependent on many factors, including but not limited to the identity of the tRNA being introduced, the genetic background of the cell, and the integration sites. Regardless, care must be taken in attributing phenotypic changes to overexpression of an individual tRNA. The increase in metabolic 
activity and cell proliferation we measure in our 184A1tRNA $_{i}^{\text {Met }}$ cell line may indeed be due to tRNA $A_{i}^{\text {Met }}$ overexpression, but also to overexpression of a number of other tRNAs or even to globally increased tRNA levels.

Our findings highlight the fact that little is known about the regulation of individual tRNA expression in the cell, and how cells respond to perturbations in tRNA levels. It is generally believed that tRNA transcription via RNA polymerase III is globally regulated in response to nutrient availability and other environmental signals, in coordination with rRNA transcription via RNA polymerase I. Current models hold that transcription at tRNA genes is coordinately regulated by shared transcription factors, acting at highly related promoter sequences (Phizicky and Hopper 2010). This view does not account for the tissue-specific differences in individual tRNA expression or the differential overexpression of individual tRNA species in breast cancer cells (Dittmar et al. 2006; Pavon-Eternod et al. 2009). A systematic study of individual tRNA expression is required to elucidate the functional significance and underlying regulatory mechanisms.

\section{MATERIALS AND METHODS}

\section{DNA vectors}

Fragments containing tRNA genes were PCR-amplified from human genomic DNA, using the following primer pairs: $5^{\prime}$-TGAG TTGGCAACCTGTGGTA and 5'-TTGGGTGTCCATGAAAATCA for $\mathrm{tRNA}_{\mathrm{i}}^{\mathrm{Met}}, 5^{\prime}$-AGCGACCTTCCCACA and 5'-GTCTCCCATT CCTACACG for $\mathrm{tRNA}_{\mathrm{e}}^{\mathrm{Met}}$. These fragments were cloned into the pTarget Mammalian Expression vector (Promega) following the manufacturer's instructions.

\section{Cell lines}

All cell lines were purchased from American Type Culture Collection (ATCC). MCF10A and 184A1 cells were cultured in 1:1 DMEM/F12 with $2.5 \mathrm{mM} \mathrm{L-Gln}$ and $15 \mathrm{mM}$ HEPES (Thermo Scientific HyClone) supplemented with 10\% FBS, 1\% Penicillin/ Streptomycin, $5 \mu \mathrm{g} / \mathrm{mL}$ insulin, $10 \mathrm{ng} / \mathrm{mL}$ EGF, and $0.5 \mu \mathrm{g} / \mathrm{mL}$ hydrocortisone. MDA-MB-231 and BT-474 were cultured in RPMI $16401 \times$ medium (Thermo Scientific HyClone) supplemented with $10 \%$ FBS and 1\% Penicillin/Streptomycin.

To generate stable cell lines, cells were transfected using Amaxa Nucleofector technology (LonzaBio). After 48 h, medium was supplemented with $500 \mu \mathrm{g} / \mathrm{mL}$ G418 (Sigma) for selection. After 2-4 wk, G418 resistant colonies appeared and the G418 concentration was scaled down to $200 \mu \mathrm{g} / \mathrm{mL}$. Medium was supplemented with $200 \mu \mathrm{g} / \mathrm{mL}$ G418 for routine culture.

\section{Transfer RNA microarrays}

Total RNA for each cell line was obtained at 80\%-90\% confluency using the miRVana miRNA Isolation Kit (Ambion). This procedure isolates RNA species as short as $15 \mathrm{nt}$ and is therefore not biased against tRNA. Total RNA quality was verified by agarose gel electrophoresis.
The tRNA microarray experiment consists of four steps starting from total RNA: (1) deacylation to remove any amino acids still attached to the tRNA, (2) selective fluorophore labeling of tRNA, (3) hybridization, and (4) data analysis. The tRNA microarray method, including reproducibility and result validation by Northern blot, has been extensively described in previously published papers (Dittmar et al. 2004, 2006; Pavon-Eternod et al. 2009, 2010; Zhou et al. 2009).

\section{Dot blots}

The following DNA probes, identical to those spotted on the tRNA microarrays, were used to quantify tRNA $A_{i}^{\mathrm{Met}}$ and $\mathrm{tRNA}_{\mathrm{e}}^{\mathrm{Met}}$ in total RNA: 5'-AGCAGAGTGGCGCAGCGGAAGCGTGCTGGGCCCAT AACCCAGAGGTCGATGGATCGAAACCATCCTCTGCTA-3' for tRNA $_{i}^{\mathrm{Met}}$, and 5'-GCCYYCTTAGCGCAGYDGGCAGCGCGTCA GTCTCATAATCTGAAGGTCCTGAGTTCGAGCCTCAGAGRGGG CA-3' for tRNA $\mathrm{e}_{\mathrm{e}}^{\mathrm{Met}}$. Probes were $5^{\prime}$-radiolabeled using T4 polynucleotide kinase and $\gamma^{-32} \mathrm{P}$-ATP (Perkin-Elmer), followed by purification on a denaturing urea polyacrylamide gel. To detect $\mathrm{RNA}_{\mathrm{i}}^{\mathrm{Met}}$ and tRNA $_{e}^{\text {Met }}$ in total RNA, 100 ng total RNA was spotted and UV crosslinked on a Hybond XL membrane (GE Healthcare). The membrane was pre-hybridized in hybridization buffer $(300 \mathrm{mM} \mathrm{NaCl}, 1 \%$ SDS, $20 \mathrm{mM}$ phosphate buffer $\mathrm{pH} 7$ ) for $30 \mathrm{~min}$ at room temperature, then hybridized overnight at $60^{\circ} \mathrm{C}$ in hybridization buffer containing $100,000-300,000 \mathrm{cpm}$ of the radiolabeled probe. The membrane was then washed three times for $20 \mathrm{~min}$ at room temperature in wash buffer ( $300 \mathrm{mM} \mathrm{NaCl}, 0.1 \%$ SDS, $20 \mathrm{mM}$ phosphate buffer $\mathrm{pH}$ 7, 2 mM EDTA). Phosphorimaging was used to quantify the amount of $\mathrm{tRNA}_{\mathrm{i}}^{\mathrm{Met}}$ and $\mathrm{TRNA}_{\mathrm{e}}^{\mathrm{Met}}$ present in each sample.

\section{Metabolic activity assays}

Cells were plated in $100 \mu \mathrm{L}$ medium in 96-well plate at the following cell densities: 500, 1000, 2000, 4000, and 8000 cells/well. For WST1 assays: $10 \mu \mathrm{L}$ WST1 reagent (Roche 05015944 001) was added to each well. Absorbance at $440 \mathrm{~nm}$ was read after $1 \mathrm{~h}$ incubation at $37^{\circ} \mathrm{C}$. For Calcein AM assays: Cells were incubated in $200 \mu \mathrm{L}$ Calcein AM (BD 354216) working solution (1 $\mu \mathrm{M}$ in HBSS) for $1 \mathrm{~h}$ at $37^{\circ} \mathrm{C}$. Fluorescence was measured at $490 \mathrm{ex} / 520 \mathrm{em}$.

\section{Cell proliferation assays}

Cell proliferation was measured over $5 \mathrm{~d}$ using Hoechst DNA staining (Invitrogen H1398). Cells were plated in $100 \mu \mathrm{L}$ medium at 500 cells/well in 96-well plates. To stain DNA, cells were incubated in $100 \mu \mathrm{L}$ of $0.1 \mu \mathrm{g} / \mathrm{mL}$ Hoechst solution in HBSS for $1 \mathrm{~h}$ at $37^{\circ} \mathrm{C}$. After washing with HBSS to remove any unbound dye, fluorescence was measured $355 \mathrm{ex} / 460 \mathrm{em}$. Fluorescence is directly proportional to the number of cells present, regardless of cell type.

\section{Statistical significance}

$T$-tests and one-sample $t$-tests were performed using GraphPad QuickCalcs (http://www.graphpad.com/quickcalcs/contMenu/).

\section{ACKNOWLEDGMENTS}

This work was supported by a grant from CDMRP (W81XWH-101-0452, 10-1-0453 to T.P. and M.R.R.). M.P.-E. was supported in 
part by a Ruth Kirshstein Pre-doctoral Fellowship from the NIH (1F31CA139968).

Received November 26, 2012; accepted January 23, 2013.

\section{REFERENCES}

Agris PF, Vendeix FA, Graham WD. 2007. tRNA's wobble decoding of the genome: 40 years of modification. J Mol Biol 366: 1-13.

Alexandrov A, Chernyakov I, Gu W, Hiley SL, Hughes TR, Grayhack EJ, Phizicky EM. 2006. Rapid tRNA decay can result from lack of nonessential modifications. Mol Cell 21: 87-96.

Anderson J, Phan L, Cuesta R, Carlson BA, Pak M, Asano K, Bjork GR, Tamame M, Hinnebusch AG. 1998. The essential Gcd10p-Gcd14p nuclear complex is required for 1-methyladenosine modification and maturation of initiator methionyl-tRNA. Genes Dev 12: 36503662.

Bjornsti MA, Houghton PJ. 2004. Lost in translation: Dysregulation of cap-dependent translation and cancer. Cancer Cell 5: 519-523.

Borel F, Hartlein M, Leberman R. 1993. In vivo overexpression and purification of Escherichia coli tRNA ${ }^{\text {ser }}$. FEBS Lett 324: 162-166.

Buvoli M, Buvoli A, Leinwand LA. 2000. Suppression of nonsense mutations in cell culture and mice by multimerized suppressor tRNA genes. Mol Cell Biol 20: 3116-3124.

Carbon P, Haumont E, Fournier M, de Henau S, Grosjean H. 1983. Sitedirected in vitro replacement of nucleosides in the anticodon loop of tRNA: Application to the study of structural requirements for queuine insertase activity. EMBO J 2: 1093-1097.

Chen W, Bocker W, Brosius J, Tiedge H. 1997a. Expression of neural BC200 RNA in human tumours. J Pathol 183: 345-351.

Chen W, Heierhorst J, Brosius J, Tiedge H. 1997b. Expression of neural BC1 RNA: Induction in murine tumours. Eur J Cancer 33: 288-292.

Dieci G, Fiorino G, Castelnuovo M, Teichmann M, Pagano A. 2007. The expanding RNA polymerase III transcriptome. Trends Genet 23: 614-622.

Dittmar KA, Mobley EM, Radek AJ, Pan T. 2004. Exploring the regulation of tRNA distribution on the genomic scale. J Mol Biol 337: 31-47.

Dittmar KA, Goodenbour JM, Pan T. 2006. Tissue-specific differences in human transfer RNA expression. PLoS Genet 2: e221.

Geiduschek EP, Kassavetis GA. 2001. The RNA polymerase III transcription apparatus. J Mol Biol 310: 1-26.
Geslain R, Cubells L, Bori-Sanz T, Alvarez-Medina R, Rossell D, Marti E, Ribas de Pouplana L. 2010. Chimeric tRNAs as tools to induce proteome damage and identify components of stress responses. Nucleic Acids Res 38: $\mathrm{e} 30$.

Kadaba S, Krueger A, Trice T, Krecic AM, Hinnebusch AG, Anderson J. 2004. Nuclear surveillance and degradation of hypomodified initiator tRNA ${ }^{\text {Met }}$ in S. cerevisiae. Genes Dev 18: 1227-1240.

Kadaba S, Wang X, Anderson JT. 2006. Nuclear RNA surveillance in Saccharomyces cerevisiae: Trf4p-dependent polyadenylation of nascent hypomethylated tRNA and an aberrant form of 5S rRNA. RNA 12: 508-521.

Kohrer C, Xie L, Kellerer S, Varshney U, RajBhandary UL. 2001. Import of amber and ochre suppressor tRNAs into mammalian cells: A general approach to site-specific insertion of amino acid analogues into proteins. Proc Natl Acad Sci 98: 14310-14315.

Marshall L, White RJ. 2008. Non-coding RNA production by RNA polymerase III is implicated in cancer. Nat Rev Cancer 8: 911914.

Pandolfi PP. 2004. Aberrant mRNA translation in cancer pathogenesis: An old concept revisited comes finally of age. Oncogene 23: 31343137.

Pavon-Eternod M, Gomes S, Geslain R, Dai Q, Rosner MR, Pan T. 2009. tRNA over-expression in breast cancer and functional consequences. Nucleic Acids Res 37: 7268-7280.

Pavon-Eternod M, Wei M, Pan T, Kleiman L. 2010. Profiling non-lysyl tRNAs in HIV-1. RNA 16: 267-273.

Phizicky EM, Hopper AK. 2010. tRNA biology charges to the front. Genes Dev 24: 1832-1860.

Sorensen MA, Elf J, Bouakaz E, Tenson T, Sanyal S, Bjork GR, Ehrenberg M. 2005. Over expression of a tRNA ${ }^{\text {Leu }}$ isoacceptor changes charging pattern of leucine tRNAs and reveals new codon reading. J Mol Biol 354: 16-24.

Vanacova S, Wolf J, Martin G, Blank D, Dettwiler S, Friedlein A, Langen H, Keith G, Keller W. 2005. A new yeast poly(A) polymerase complex involved in RNA quality control. PLoS Biol 3: e189.

Waas WF, Druzina Z, Hanan M, Schimmel P. 2007. Role of a tRNA base modification and its precursors in frameshifting in eukaryotes. J Biol Chem 282: 26026-26034.

Winter AG, Sourvinos G, Allison SJ, Tosh K, Scott PH, Spandidos DA, White RJ. 2000. RNA polymerase III transcription factor TFIIIC2 is overexpressed in ovarian tumors. Proc Natl Acad Sci 97: 12619-12624.

Zhou Y, Goodenbour JM, Godley LA, Wickrema A, Pan T. 2009. High levels of tRNA abundance and alteration of tRNA charging by bortezomib in multiple myeloma. Biochem Biophys Res Commun 385: 160-164. 

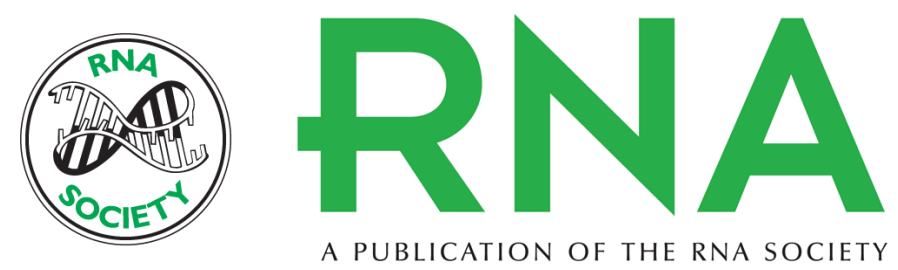

\section{Overexpression of initiator methionine tRNA leads to global reprogramming of tRNA expression and increased proliferation in human epithelial cells}

Mariana Pavon-Eternod, Suzana Gomes, Marsha R. Rosner, et al.

RNA 2013 19: 461-466 originally published online February 19, 2013

Access the most recent version at doi:10.1261/rna.037507.112

References This article cites 27 articles, 9 of which can be accessed free at: http://rnajournal.cshlp.org/content/19/4/461.full.html\#ref-list-1

License

Email Alerting Receive free email alerts when new articles cite this article - sign up in the box at the Service top right corner of the article or click here. 